International Journal of Current Advanced Research

ISSN: O: 2319-6475, ISSN: P: 2319 - 6505, Impact Factor: SJIF: 5.995

Available Online at www.journalijcar.org

Volume 6; Issue 3; March 2017; Page No. 2938-2940

DOI: http://dx.doi.org/10.24327/ijcar.2017.2940.0147

Research Article

\title{
ASSESSING DIFFICULTIES ENCOUNTERED BY DENTAL STUDENTS STUDYING ORAL PATHOLOGY AMONG UNDERGRADUATES
}

\author{
Syed Shihaab, $S$ and Gheena, $S$
}

Department of Oral Pathology, Saveetha Dental College

\begin{tabular}{l}
\hline A R T I C L E I N F O \\
\hline Article History: \\
Received $25^{\text {th }}$ December, 2016 \\
Received in revised form $24^{\text {th }}$ January, 2017 \\
Accepted $4^{\text {th }}$ February, 2017 \\
Published online $28^{\text {th }}$ March, 2017
\end{tabular}

Key words:

Difficulties encountered, Oral pathology

\begin{abstract}
A B S T R A C T
Aim: To determine Difficulties Encountered by Dental Students Studying Oral Pathology and Addressing Their Concerns.

Objective: This research is done to have a detailed idea on various Difficulties Encountered by Dental Students Studying Oral Pathology and Addressing Their Concerns

Back Ground: The present scenario of Oral Pathology and Oral Histology as a subject is alarming. In spite of so many advancements in terms of books, internet and conferences there are still lacunae between the understanding and interest for the subjects in the students. It can be partly due to the fact that the students perceive it as a non-clinical subject having a lesser scope for practice.

Reason: This research is done to have a detail idea on Difficulties Encountered by Dental Students Studying Oral Pathology.
\end{abstract}

Copyright $\odot 2017$ Syed Shihaab, S and Gheena, S. This is an open access article distributed under the Creative Commons Attribution License, which permits unrestricted use, distribution, and reproduction in any medium, provided the original work is properly cited.

\section{INTRODUCTION}

The prime consideration about higher education is to strengthen students' abilities and skills so as to transform them to become competent graduates. In a single class in general there are different students with wide variation in their intellectual level or the understanding level [1]. The basis for becoming a good dental student is dependent on their ability to identify pathological diseases under a microscope. This can be achieved by reading books, exhaustive literature, and following the prescribed curriculum [2]. Department of oral pathology has its role in training dntal students. We decided to concentrate on the role played by department of oral pathology. This dental specialty identifies and manages diseases affecting oral and maxillofacial regions and investigates the cause, processes and effect of these diseases. According to this speciality, students are uniquely trained to professionally address both diagnosis and treatment of oral diseases, which will aid rapid critical connection between oral and systemic diseases and combine expertise in histopathological diagnosis with clinical diagnosis and treatment outcome [3]. Fortunately as the students now have a good access to the electronic media such as internet, Google, etc., which makes them more vulnerable to the ever changing pathological world. Undoubtedly, perfection in this speciality is achieved by spending more hours in front of microscope. In spite of a good and standardized academic curriculum and a decent enough infrastructure, there is still a gap between the

*Corresponding author: Syed Shihaab, $\mathbf{S}$

Department of Oral Pathology, Saveetha Dental College student's understanding and teacher's training. As far as our knowledge goes, there are no studies carried out in this respect. Keeping this in mind we tried to assess the difficulties encountered by dental students in Oral Pathology thereby bridging the gap in order to facilitate a conducive environment for the budding dentists.

\section{MATERIALS AND METHOD}

A cross sectional study was conducted among dental students of Saveetha dental college and other college. This survey assessed the Difficulties Encountered by Dental Students Studying Oral Pathology

\section{Data Collection}

A Questionnaire consisting of 19 questions on difficulties encountered by dental students studying oral pathology was circulated to the students of third year of saveetha dental college and other neighbouring colleges. It aimed at assessing the difficulties encountered by dental students studying oral pathology.

\section{RESULT}

1. Do you attend lectures which discuss slides before they are shown?

2. Do you feel it is necessary to explain the slides before they are focused?

3. Is light microscope good for you to study the slides?

4. Do you know that there are microscopes other than light microscopes? 
5. Are running slides given to you or are they stipulated teaching slides?

6. Do you feel difficulty in focussing slides

7. Are you able to differentiate between ground sections and decalcfied sections (for examination of teeth and bone)?

8. Do you make an effort to read the topic before you see the slide?

9. Have you heard about special stains?

10. Is internet a good source for understanding oral pathology slides?

11. Do you feel that more hours should be put in by the student to increase understanding?
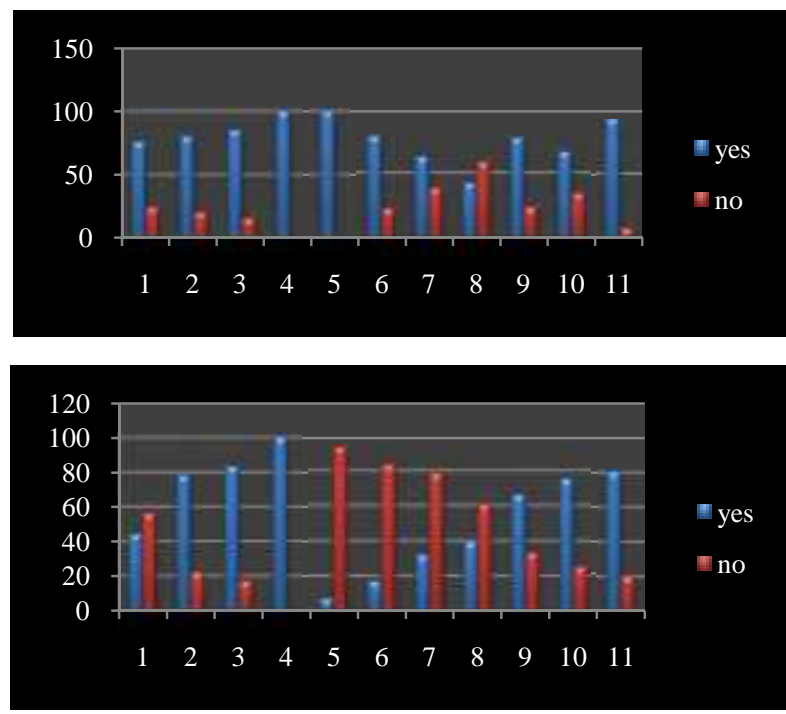

Fig 1 How many hours do you spend in the department of oral pathology in a week for practical knowledge

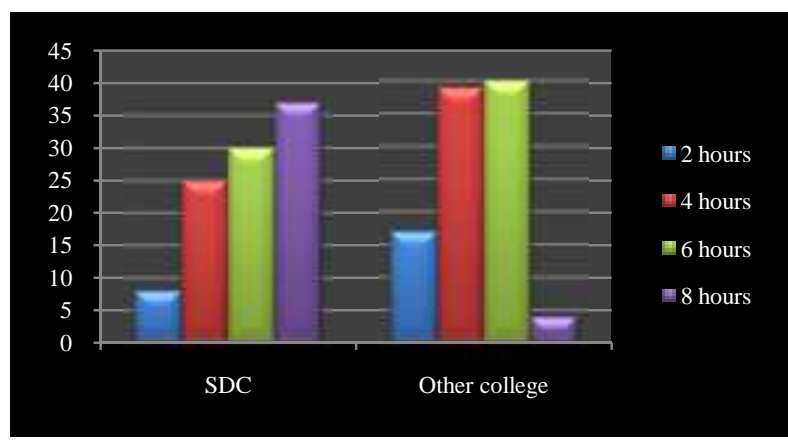

Graph 1 It is seen that students of saveetha dental college on an average spend more time in department of oral pathology than other college sudents, in order to have better practical knowledge.

Fig 2 How many slides do you see on an average in one practical class?



Graph 2 shows that students of other colleges observe more number of slides in one practical class than the students of saveetha dental college.

Fig 3 How do you actually identify the slide?

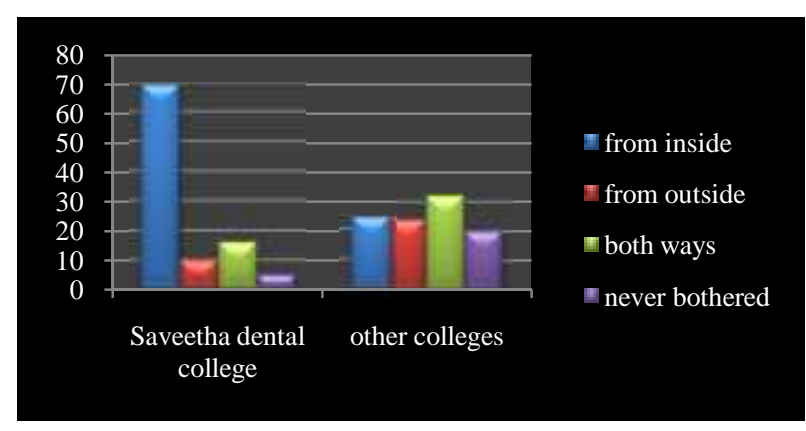

Graph 3 shows that studnts of saveetha dental college use conventional technique of identifying slides rather than any other techniques

Fig 4 Dou focus the slides or are focused slides given to you

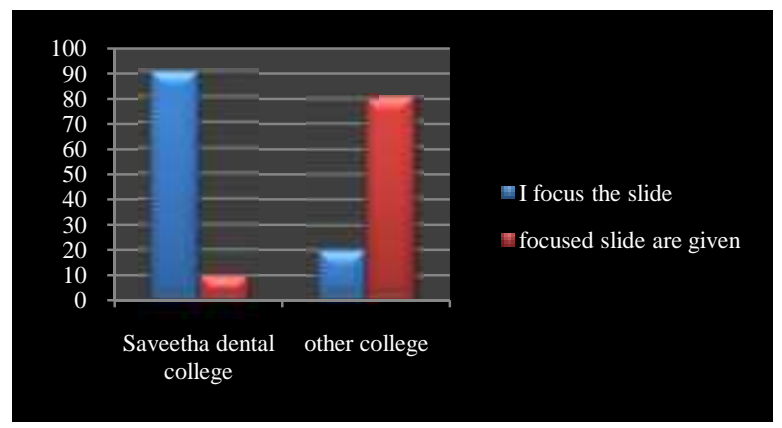

Graph 4 shows that students in saveetha dental college are given running slides to focus rather than focused slide which is followed in neghbouring colleges.

Fig 5 How well can you identify the features on a slide after seeing it for the first time?

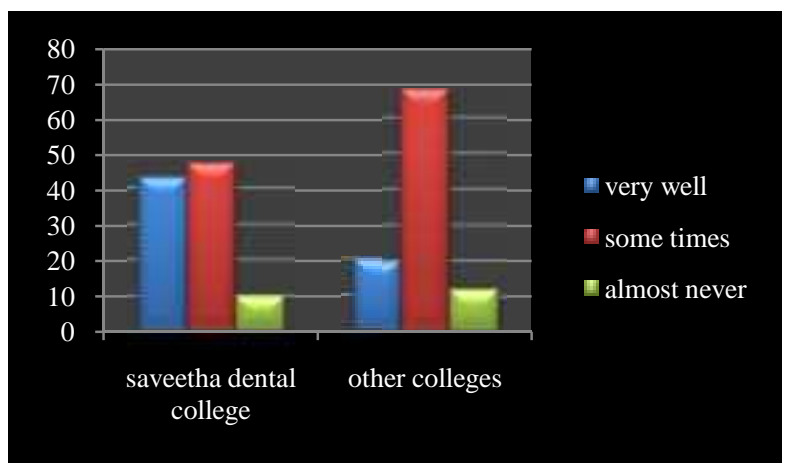

Graph 5 shows that students of saveetha dental college were confident enough in identifying the given slides when compared to students of other colleges.

Fig 6 How often do you practice to draw the diagrams?

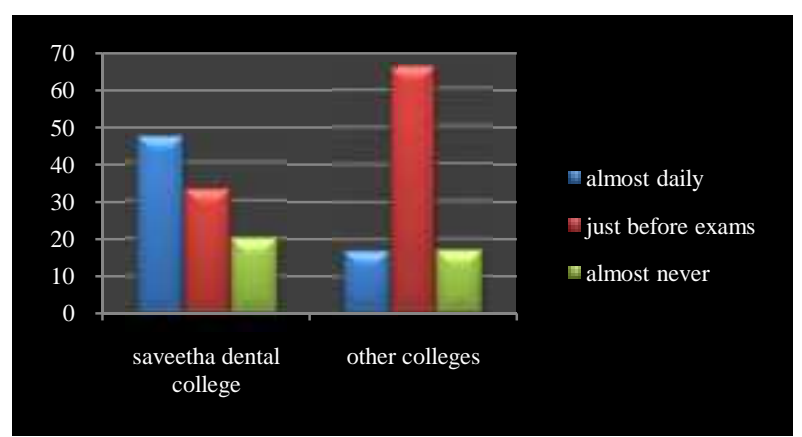

Graph 6 shows that histopathological diagrams of the practical slides were regularly practised by the students of saveetha dental college. 
Fig 7 How often have you attended seminars/continuing dental education programs/ conferences/symposiums related to Oral Pathology?

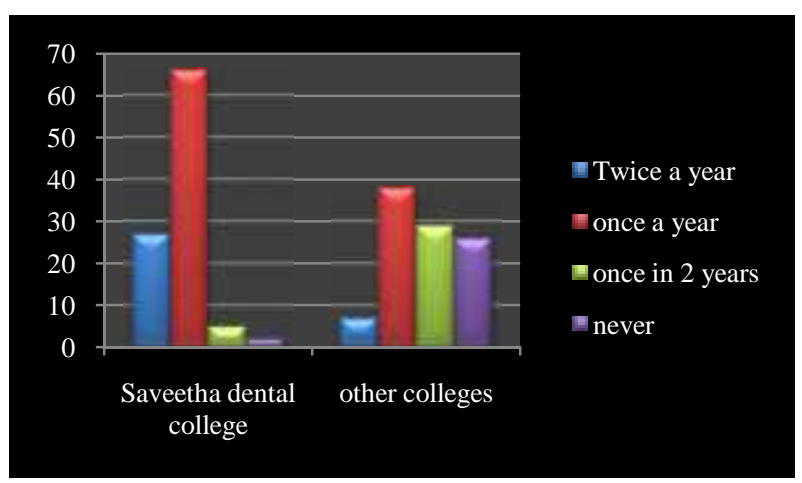

Graph 7 shows that students of saveetha dental college are very much exposed to seminars and conferences than students of other dental colleges

\section{DISCUSSION}

This study gives us a detail idea on difficulties encountered by dental students studying oral pathology and addressing their concern. In this study, various aspects related to oral pathology were discussed with the help of a questionnaire. Around 310 dental colleges are currently there in India [4, 5]. This reflects that India is one of the largest producers of dental graduates in the world. A good dental practioner is built on knowledge and understanding of pathological diseases at microscopic level. This make students develop interest in Oral Pathology [6]. This study had a reasonably decent sample size and the response was $100 \%$.

Our study showed that $38 \%$ third year students of saveetha dental college spent 8 hours or more in the department wheras other college students spent on an average 5 hours a day in the department for practical knowledge. In most of the international universities, the number of hours spent are more or less the same. Most of the participants $(80 \%)$ confirmed that it is beneficial for them to attend lectures, while only $20 \%$ participants agreed that they faced difficulty and approached the teachers for the same. It was observed that nearly $80 \%$ of saveetha dental college participants studied 2 slides per class whereas in other college they reported to observe 4 slides per class. Nearly all the participants answered 'yes' for making record books. Most of the respondents were satisfied with light microscope for studying slides and they were aware of other microscopes also. We believe that if the students take interest in histology technique or rather if they are given an exercise to prepare a microscopic slide of a tissue, it would further generate enthusiasm in them and they would get closer to Oral Pathology by following this technique students in saveetha dental college are trained in the department of pathology. Total of $70 \%$ participants could "sometimes" identify the features on a slide after seeing it for the first time. More than half of the participants confirmed that they read the topic before seeing the slides; however, $70 \%$ participants felt that their main difficulty was identification of slide while $30 \%$ were having difficulty in remembering it for exam. A maximum group of students stressed that internet could be of help sometimes and was a good source for understanding Oral Pathology slides. Most of the students also felt the need for more interactive sessions with the faculty. $60 \%$ said that they can improve if they are further motivated by the means of quiz competition, while $40 \%$ reported that the improvement can be done through awards.

Sciubba JJ et al., also reported that students do get motivated if there is some kind of incentive. Students who combine their academic knowledge and clinical diagnosis can be rewarded. This is only possible if the students get posted to Oral Medicine and Oral Radiology department more often where they can sharpen their skills [7]. This study gave us an insight to the student's difficulties and apprehensions. One novel idea to enhance performance is by having digitalization of slides. Few studies have shown that students find it easier and can relate well as compared to conventional slides [8, 9]. Tamgadge $\mathrm{S}$ had made a novel suggestion to take a bold initiative so as to improve student learning by adding 3D animation technology in Oral Pathology. This student friendly approach may help in reviving Oral Pathology subject, thereby trying to make it one of the most sought after branch in dentistry [10].

\section{CONCLUSION}

Through the present study it was found out that the students were well oriented on the whole about Oral Pathology. It was seen that the no. Of slides seen per class should be increased I.e. Their focussing ability should be increased. And regular revisions should be conducted as many complained they concentrated much on academics just before exams. Through the present study we would like the readers to be aware of the changing trends in teaching and to incorporate them routinely.

\section{Reference}

1. Priya M, Muthu MS, Amarlal D, Thomas E, Continuou $\mathrm{s}$ assessment of undergraduate students at a dental college in India J Dent Educ 2012 76:501-08.

2. Yip HK, Smales RJ, Review of competency-based education in dentistry Br Dent J 2000 189:324-26.

3. American Academy of Oral \& Maxillofacial Pathology. [Last cited on 2016 Mar]. Available from: http://www.aaomp.org/

4. Database of Dental Council of India. [Last cited on 2015 Oct]. Available from: http://www.dciindia.org/ search.aspx

5. Dagli N, Dagli R, Increasing unemployment among Indian dental graduates - High time to control dental manpower J Int Oral Health 2015 7(3):i-ii.

6. Wright JM, Vincent SD, Muller S, McClatchey KD, B udnick SD, Murrah VA, The future of oral and maxillofacial pathology Oral Surg Oral Med Oral Pathol Oral Radiol Endod 2003 96(2):176-86.

7. Sciubba JJ, Oral and maxillofacial pathology-Its future in doubt? J Dent Educ 2001 65(11):1194-95.

8. Fonseca FP, Santos-ilva AR, Lopes MA, Almeida OP, Vargas PA, Transition from glass to digital slide microscopy in the teaching of oral pathology in a Brazilian dental school Med Oral Patol Oral Cir Bucal 2015 20:e17-22.

9. Krippendorf BB, Lough J, Complete and rapid switch from light microscopy to virtual microscopy for teaching medical histology Anat Rec B New Anat 2005 285(1):19-25.

10. Tamgadge S, Malathi N, From the author's desk J Oral Maxillofac Pathol 2015 19:273-74. 